\title{
The Quality of Corporate Reporting of Non-Financial Companies Listed on Abu Dhabi Securities Exchange (ADX)
}

\author{
Shakikh Hazza Bin Tahnoun Al Nehayan ${ }^{1} \&$ Kamal Naser ${ }^{2}$ \\ ${ }^{1}$ H. H. Undersecretary, Ruler's Representative Court, Eastern Region, UAE \\ ${ }^{2}$ Economic and Financial Advisor, Kuwait Fund, UK \\ Correspondence: Kamal Naser, Economic and Financial Advisor, 36 Amesbury Road, Penylan, Cardiff CF23 \\ 5DX, UK. E-mail: profnaser@yahoo.co.uk
}

Received: March 31, 2015

Accepted: April 27, 2015

Online Published: July 25, 2015

doi:10.5539/ijef.v7n8p1

URL: http://dx.doi.org/10.5539/ijef.v7n8p1

\begin{abstract}
The objective of this study is to explore factors influencing the quality of corporate reporting of non-financial companies listed on Abu Dhabi Securities Exchange (ADX). To achieve this objective, the annual reports of all non-financial companies listed on ADX for the years 2010-2012 are used to develop a proxy of the quality of corporate reporting and extract possible variables explaining the quality of corporate reporting. Variables employed in this study are size, profitability, leverage, age, industry type, percentage of shares owned by government, cash dividends, and presence of dominant personality serving on the company's board of directors. The results of the analysis revealed that the quality of corporate reporting of the non-financial companies listed on ADX is relatively high ( $83 \%$ of the expected disclosure). The analysis further pointed to positive and statistically significant association between the quality of corporate reporting and variables such as size, industry type, leverage and age. On the other hand, negative and statistically significant association appeared between the quality of corporate reporting and the presence of dominant personalities on the company's board of directors.
\end{abstract}

Keywords: quality of corporate reporting, emerging economy, Abu Dhabi

\section{Introduction}

Corporate reporting is designed to communicate information about a firm to assist various interested parties in making informed investment decisions. In other words, the quality of the reported information assists in making useful investment decisions about the firm in question. The quality of corporate financial is, therefore, vital in investment decision-making. Thus, the broad objective of this study is to investigate the quality of corporate reporting of non-financial companies listed on ADX.

The importance of this study stems from the fact that oil producing countries such as UAE and other Gulf Cooperation Council (GCC) countries are experiencing fluctuations in oil prices and depletion in oil reserves (Note 1). They are developing plans to minimize their reliance on oil revenues and attempting to diversify their economies. One of the main objectives of the plans is to attract foreign investment and it is for this reason Abu Dhabi authorities established ADX. In this respect, it can be argued that good quality financial reporting positively affect the development of the financial and the private sectors, which in turn results in economic development and economic growth. The relationship between good quality financial reporting and the development of the financial and private sectors can be explained on the grounds that good quality financial reporting will minimize financial markets risk and will have positive impact on the economy at large. In addition, good quality financial reporting may attract direct foreign investment and this would help in mobilizing domestic savings. Moreover, good quality financial reporting assists users in identifying profitable companies and making informed decisions that result in low cost of capital and better allocation of resources. Hence, corporate financial reporting is viewed as being an important factor in a well-functioning market economy and a robust financial system. It is, therefore, vital to study determinants of quality of corporate reporting of non-financial companies listed on Abu Dhabi Securities Exchange (ADX) (Note 2).

The reminder of the study is organized as follows. A review of previous related studies and hypotheses development are presented in the following section. Data collection and study methodology are explained in section three. While the empirical findings are discussed in section four, the conclusion is offered in the last 
section.

\section{Previous Related Studies and Hypotheses Development}

Over the last five decades, numerous studies were undertaken to identify factors affecting the quality of corporate reporting. Among these factors were corporate size, industry type, corporate age, percentage of sharers owned by government and levels of corporate leverage. In addition to these variables frequently employed in previous research to explain variation in the quality of corporate reporting, two variables will be employed in the current study; the presence of dominant personalities serving on corporate board of directors and cash dividends. Literature related to each of these variables will be reviewed in the succeeding sections.

\subsection{Corporate Size}

Significant number of studies investigated the relationship between the quality of corporate reporting and corporate size. Large sized companies are expected to have resources to compile and disclose information more than small companies. Since they have the resources, they can afford to hire one of the Big Four international audit firms. Companies audited by one of the Big Four international audit firs would have better disclosure than firms audited by small audit firms. Large companies are closely monitored by the stock markets more than small companies. As a consequence, they are subjected to the scrutiny of the public. To assure the public, they tend to disclose more information than small companies. Needless to say, large companies are more likely to be involved in activities that require disclosure more than small companies. Hence, size has been used in previous studies to explain the quality of corporate reporting.

Different measures employed in the literature to proxy size. Several studies, however, used total assets to proxy size (see for example: Singhvi, 1968; Singhvi \& Desai, 1971; Buzby, 1975; McNally et al., 1982; Cooke, 1989a, 1989b; Cooke, 1992; Malone et al., 1993; Wallace et al., 1994; Wallace \& Naser, 1995; Inchausti, 1997; Owusu-Ansah, 1998; Tower et al., 1999; Haniffa \& Cooke, 2002; Bujaki \& McConomy, 2002; Naser et al., 2002; Camfferman \& Cooke, 2002; Chu \& Gray, 2002; Ferguson et al., 2002; Barako, 2006, Othman et al., 2009; Hossain \& Hammami, 2009; Aly et al., 2010; Galani et al., 2011; Juhmani, 2013; Haji \& Ghazali, 2013; Suleiman et al., 2014). Other researchers used total sales to proxy corporate size (see for example: Cooke, 1989a \& b; Cooke, 1992; Wallace et al., 1994; Meek et al., 1995; Raffournier, 1995; Inchausti, 1997; Depoers, 2000; Naser et al., 2002; Prencipe, 2004; Uyar, 2012). Most of these studies reported significant and positive association between the quality of disclosure and corporate size. It is, therefore, hypothesized:

Hypothesis 1: The quality of corporate reporting of non-financial companies listed on ADX is positively associated with corporate size measured by total assets.

\subsection{Profitability}

Profitability is another factor advanced in the literature to explain the quality of corporate reporting. Corporate profitability gives indication about management effectiveness. A profitable company would provide detailed information in order signal information about management success. Profitable companies have good news to pass on to the users of their accounts. Hence, they are more likely to disclose more information than non-profitable companies. However, in some cases where companies sustain losses, management of these companies may provide detailed information to explain why they sustained losses.

Numerous studies used profitability to explain variations in the quality of corporate reporting (see for example: Singhvi, 1968; Singhvi \& Desai, 1971; McNally et al., 1982; Malone et al., 1993; Wallace et al., 1994; Meek et al., 1995; Raffournier, 1995; Wallace \& Naser, 1995; Inchausti, 1997; Owusu-Ansah, 1998; Tower et al., 1999; Haniffa \& Cooke, 2002; Naser et al., 2002; Camfferman \& Cooke, 2002; Chau \& Gray, 2002; Glaum \& Street, 2003; Prencipe, 2004; Akhtaruddin, 2005; Al-Shammari, 2008; Barako, 2006, Hossain \& Hammami, 2009; Othman et al., 2009; Aly et al., 2010; Galani et al., 2011; Juhmani, 2013; Suleiman et al., 2014). Different measures were used to proxy profitability such as rate of return, earnings margin, net income to total assets, net income to sales, earnings to sales, return on assets, operating profit to total asset, profit margin, net income to equity, return on capital employed and return on equity. The vast majority of the above mentioned studies showed positive and significant relationship between the quality of corporate disclosure and profitability. It is, therefore, hypothesized:

Hypothesis 2: The quality of corporate reporting of non-financial companies listed on ADX is positively associated with corporate profitability measured by return on assets.

\subsection{Leverage}

Leverage is an additional factor used in the literature to explain the quality of corporate reporting (see for 
example: Chow \& Wang-Boren, 1987; Malone et al., 1993; Wallace et al., 1994; Meek et al., 1995; Raffournier, 1995; Inchausti, 1997; Tower et al., 1999; Depoers, 2000; Haniffa \& Cooke, 2001; Bujaki \& McConomy, 2002; Camfferman \& Cooke, 2002; Ferguson, Lam, \& Lee, 2002; Naser et al., 2002; Prencipe, 2004; Al-Shammari, 2008; Barako, 2007; Aly et al., 2010; Juhmani, 2013; Suleiman et al., 2014). Companies with high leverage ratios will be asked by the lenders to disclose more information than those with low leverage ratio. Lenders request detailed information before granting loans. In general, banks and other lending organizations are more likely to render money to successful and reputable firms. Such firms are expected to disclose more information than other firms in order to satisfy the banks and other lending organizations demand.

Different measures have been used in the above-mentioned studies to proxy leverage including total liabilities to total assets, total liabilities to total equity, long-term liabilities to equity and total liabilities to total equity. Most of these study reported positive and significant association between level of leverage and the quality of corporate reporting. It is, therefore, hypothesized that:

Hypothesis 3: The quality of corporate reporting of non-financial companies listed on ADX is positively associated with corporate level of leverage measured by total liabilities to total assets.

\subsection{Corporate Age}

Corporate age is an additional variable used in the literature to explain the quality of corporate reporting (see for example: Owusu Ansah, 1998; Haniffa \& Cooke, 2002; Glaum \& Street, 2003; Akhtaruddin, 2005; Al-Shammari, 2008; Hossain \& Hammami, 2009; Galani et al., 2011; Al-Shubiri, 2013). Well established companies try to maintain a good reputation to the external market. When a company stays in business for a long time, this indicates success and this would be reflected in the quality of its reporting. In addition, staying in business for a long time results in accumulation of information about the company and this would be reflected in corporate disclosure. On other hand, it is understandable for newly-established companies to undertake fewer activities than the well-established ones. Hence, they do not have enough information to disclose. Yet, some young companies might have the motive to disclose detailed information to prove that they can compete with the well established companies.

Empirical evidence on the relationship between corporate age and the quality of corporate disclosure is mixed. While some of the above-mentioned studies reported a positive and significant relationship between age and the quality of corporate reporting, other studies found insignificant association between the two variables. It, therefore, hypothesized that:

Hypothesis 4: The quality of corporate reporting of non-financial companies listed on ADX is associated with corporate age measured by the number of years between the year of company's establishment and 2012.

\subsection{Industry Type}

Industry is another variable frequently used in previous studies to explain variations in the quality of corporate reporting among companies (see for example: McNally et al., 1982; Cooke, 1989; Cooke, 1992; Meek et al., 1995; Raffournier, 1995; Inchausti, 1997; Owusu-Ansah, 1998; Tower et al., 1999; Haniffa \& Cooke, 2002; Camfferman \& Cooke, 2002; Chau \& Gray, 2002; Ferguson et al., 2002; Naser et al., 2002; Glaum \& Steet, 2003; Akhtaruddin, 2005; Al-Shammari, 2005; Barako, 2007; Hossain \& Hammami, 2009; Othman et al., 2009; Aly et al., 2010; Galani et al., 2011, Suleiman et al., 2014). Different industries mean different activities. For example, manufacturing companies are expected to be involved in more activities than services companies since they have to purchase different types of materials, handle and store them. In addition, manufacturing companies will be capital intensive and require large capital investment and would seek different sources of funding. Hence, manufacturing companies are generally large in size. Thus, industry type is expected to influence the quality of corporate reporting.

Empirical evidence supports the relationship between the quality of corporate reporting and industry type. In many studies, a positive relationship appeared between manufacturing companies and the quality of corporate reporting. It is, therefore, hypothesized that:

Hypothesis 5: The quality of corporate reporting of non-financial companies listed on ADX is associated with industry type.

\subsection{Government Ownership}

Concentration of corporate ownership is more likely to ease the conflict of interest between management and shareholders; whereas widely spread corporate ownership is more likely to intensify the conflict of interest between the two parties (Fama \& Jensen, 1983). Thus, corporate ownership structure is expected to affect the 
quality of corporate reporting. The effect of corporate ownership structure and the quality of corporate reporting can be both ways. The concentration of ownership in the hands of few investors may give little incentive to management to disclose detailed information. However, majority shareholders may attempt to assure minority shareholders by demanding detailed corporate disclosure. Widely spread ownership may intensify the conflict of interest between management and shareholders and increases agency cost. Management attempts to minimize agency cost by voluntary disclosing detailed information (Craswell \& Taylor, 1992; McKinnon \& Dalimunthe, 1993). However, widely spread ownership would dilute shareholders influence on management to disclose detailed information.

In the UAE as well as other GCC countries, governments own a significant proportion of corporate shares. In this case, companies' management may have little incentive to disclose detailed information or management may set good example for other companies with low or without government ownership by disclosing more detailed information.

Empirical evidence on the relationship between the quality of corporate reporting is restricted to few studies. While Makhija and Patton (2004) found insignificant positive relationship between government ownership and corporate disclosure, Al-Janadi et al. (2013) reported negative and marginally significant relationship between corporate reporting and government ownership. It is, therefore, hypothesized that:

Hypothesis 6: The quality of corporate reporting of non-financial companies listed on ADX is associated with the percentage of shares owned by government.

\subsection{Dominant Personalities Serving in the Company's Board of Directors}

Most of the non-financial companies listed on ADX have either Shaikh or ex-minister serving on their board of directors. Presence of one or more dominant personalities on the board of directors will facilitate the completion of management transactions especially those related to government. Such presence is expected to have implication to the quality of corporate reporting. It would motivate management to disclose more detailed information to prove to the dominant personalities that they are working to the best interest of shareholders. Management would also voluntary disclose detailed information to set good example for other companies without dominant personalities serving on their board of directors. In addition, companies with one or more dominant personality serving on their board of directors will be subject to the public scrutiny and the public expect them to do better that other companies without dominant personalities. However, the presence of dominant personalities in the corporate board of directors might have negative effect on the quality of corporate reporting. Management might hide behind the name and political/social positions of these personalities and disclose less information. The relationship between the quality of corporate reporting and the presence of dominant personalities on corporate board of directors is not empirically tested before. It is therefore hypothesized that:

Hypothesis 7: The quality of corporate reporting of non-financial companies listed on ADX is associated with the presence or otherwise of dominant personalities on their board of director.

\subsection{Cash Dividends}

Dividend payout can be used by corporate managements to reduce agency cost resulted from the conflict of interest between them and shareholders. Management may opt to increase dividend payout and forces itself to borrow money to finance corporate expansion and growth. By doing so, it invites a third part (lenders) to monitor its activities in order to assure shareholders that it is working to the best of their interest. By adopting agency theory on the relationship between corporate reporting and dividend payout, companies with high dividend payout have little incentive to disclose detailed information. However, the opposite might be occurred. If company's management opts for high dividend payout and approach lenders to finance possible expansion and growth, the third party (lender) would request detailed disclosure. The relationship between dividend payout and the quality of corporate disclosure is not empirically tested in previous research. It is therefore hypothesized that:

Hypothesis 8: The quality of corporate reporting of non-financial companies listed on ADX is associated with dividend payout.

\section{Data Collection and Study Methodology}

\subsection{Data Collection}

As mentioned earlier, the current study used the annual reports of all companies listed on ADX for the years 2010-2102. ADX displays corporate profile, annual report and majority shareholders' names and the percentage of shares they own for all listed companies. At the end of 2012, 70 companies were listed on ADX. 39 companies 
were classified as financial companies and 31 non-financial companies (Note 4). However, the annual reports of one non-financial companies was not published on the ADX website due to recent listing and two none Emirate non-financial companies, Ooredoo and Sudan Telecommunication Co. Ltd., were listed on the exchange. These companies were excluded from the analysis. The breakdown number of the non-financial companies listed on the Exchange by industry is listed in Table 1 below.

Table 1. Distribution of non-financial companies listed on ADX

\begin{tabular}{lc}
\hline Sector & Number of Companies \\
\hline Services & 6 \\
Manufacturing & 14 \\
Food Staples & 4 \\
Property and Real Estate & 1 \\
Energy & 2 \\
Telecommunications & 1 \\
Total & 28 \\
\hline
\end{tabular}

\subsection{Study Methodology}

Measuring the quality of corporate reporting is not an easy task since quality itself is not readily measurable (Bernstein, 1982; Botosan, 1997). Hence, a measurable proxy of quality needs to be developed. This problem has been addressed in the literature and various approaches have been used to handle it (see for example: Chow \& Wong-Boren, 1987; Cooke, 1992, 1993; Clarkson et al., 1996; Wallace \& Naser, 1994; Naser, 1998; Aly et al., 2010). In the literature, the extent of the comprehensiveness of corporate disclosure was used to proxy the quality of reporting. The literature reviewed by Healy and Palepu (2001) indicated that more information disclosed by the firm reduces asymmetry among the users of the information. Hence, the extent of disclosure will be used to proxy the quality of the reported information. Information disclosed by non-financial companies listed on ADX were scored on the basis of IAS 1 "Presentation of financial Statements" and IAS 5 "Information to be Disclosed in Financial Statements". In the literature, two indices were used to proxy the quality of corporate disclosure: un-weighted and weighted. Under the un-weighted index, dichotomous scores are used where a zero score is given for non-disclosure and 1 score for disclosure. The weighted index, on the other hand, is based on the importance that various users of corporate reports attach to every disclosure item. Under the weighted index approach, the disclosure item will be multiplied by the average weight that the users attach to each disclosure item. In this study, the average un-weighted disclosure index for the years 2010-2011 will be used since the importance that the users assign to various items disclosed by companies listed on Abu ADX is not readily available. The literature indicated that using the un-weighted index is unlikely to affect the results (see for example: Robbins \& Austin, 1986; Chow \& Wong-Boren, 1987; Wallace \& Naser, 1995). Robbins and Austin (1986) and Chow and Wong-Boren (1987) reached the same results when they used un-weighted and weighted indices. Thus, the un-weighted index is employed in the current study. The score achieved by each company was divided on the maximum expected score to obtain the index. This can be mathematically presented as follows:

$$
U D I_{(x)}=\left[\sum_{x=1}^{n} D I_{(x)}\right] / m_{x}
$$

Where:

$U D I_{(x)}=$ Un-weighted disclosure index for company $\mathrm{x}$.

$D I_{(x)}=$ Disclosure items for company $\mathrm{x}$.

$m_{(x)}=$ Maximum score expected for company $\mathrm{x}$.

The score (index) achieved by each company will form the dependent variable will be regressed against the attributes of the company as summarized by the following regression model:

$$
U D I_{(x)}=\alpha_{0}+\beta_{1} S I Z E+\beta_{2} \text { PROFIT }+\beta_{3} L E V+\beta_{4} A G E+\beta_{5} I N D S+\beta_{6} G O V O W+\beta_{7} D O M I+\beta_{8} C D I V+\varepsilon
$$

Where:

$\mathrm{UDI}_{(\mathrm{x})}=$ Un-weighted disclosure index achieved by each company; 
$\alpha_{0}=$ Intercept;

$\beta_{1}-\beta_{8}=$ Parameters of the equation;

$S I Z E=$ Company size measured by total assets;

PROFIT $=$ Profitability measured by return on total assets;

$L E V=$ Leverage measured by total liabilities over total assets;

Age $=$ Age measure by 2012 minus date of corporate incorporation;

INDS = Industry type; Companies are categorized into six industries: Services, manufacturing, food staples, property and real estate, energy and communications;

GOVOW $=$ Percentage of shares owned by government;

$D O M I=$ Number of dominant personalities serve on the company's board of directors;

$C D I V=$ Cash dividends;

$\varepsilon=$ Standard error.

\section{Findings}

\subsection{Descriptive Statistics}

Descriptive statistics summarized in Table 2 showed the extent of disclosure by non-financial companies listed on ADX is relatively high as reflected by the reported mean and median. The table also showed that the surveyed companies vary in their size, in the level of the reported profit, in the level of leverage, in their age, the percentage of shares owned by government, the number of dominant personalities serving on their board of directors and the amounts of cash dividends. Variations in the surveyed companies' characteristics are reflected by the reported mean, standard deviation together with the minimum and maximum values. Variations in the surveyed companies' characteristics provide good ground for the analysis and give credibility to the findings.

Table 2. Descriptive statistics of variables used in the study

\begin{tabular}{|c|c|c|c|c|c|}
\hline & Mean & Median & Standard Deviation & Minimum & Maximum \\
\hline $\operatorname{Index}(X)$ & 0.83 & 0.82 & 0.06 & 0.70 & 0.96 \\
\hline SIZE (AED Millions) & 10,139 & 1,610 & 25,705 & 189 & 124,683 \\
\hline $\operatorname{PROFIT}(R O A)$ & 0.03 & 0.03 & 0.06 & -0.27 & 0.18 \\
\hline$L E V(T L / T A)$ & 0.15 & 0.08 & 0.18 & 0.00 & 0.79 \\
\hline Age (2012-Year of incorporation) & 24.50 & 31.00 & 12.18 & 6.00 & 40.00 \\
\hline \multicolumn{6}{|l|}{ INDS (Industry type) } \\
\hline $\begin{array}{l}\text { GOVOW (Percentage of shares owned by } \\
\text { government) }\end{array}$ & 0.18 & 0.03 & 0.24 & 0.00 & 0.72 \\
\hline $\begin{array}{l}\text { DOMI (presence of dominant personality on the } \\
\text { board of directors }\end{array}$ & 3.00 & 2.00 & 3.00 & 0.00 & 11.00 \\
\hline CDIV(Cash dividends; AED 000) & 222,250 & 21,063 & 877,194 & 0.00 & $4,660,000$ \\
\hline
\end{tabular}

\subsection{Correlation}

To identify possible collinearity between the independent variables used to estimate the regression model, Pearson correlation was performed and the results reported in Table 3. 
Table 3. Correlations among the explanatory variables used in the regression models

\begin{tabular}{|c|c|c|c|c|c|c|c|c|}
\hline & SIZE & PROFIT & LEV & Age & INDS & GOVOW & DOMI & CDIV \\
\hline SIZE & 1.000 & & & & & & & \\
\hline PROFIT & $\begin{array}{l}-.073- \\
0.713\end{array}$ & 1.000 & & & & & & \\
\hline LEV & $\begin{array}{l}.503 * * \\
0.006\end{array}$ & $\begin{array}{l}-.108- \\
0.585\end{array}$ & 1.000 & & & & & \\
\hline Age & $\begin{array}{l}-.315- \\
0.103\end{array}$ & $\begin{array}{l}0.066 \\
0.739\end{array}$ & $\begin{array}{l}-.310- \\
0.108\end{array}$ & 1.000 & & & & \\
\hline INDS & $\begin{array}{l}.623^{* *} \\
0\end{array}$ & $\begin{array}{l}-.262- \\
0.178\end{array}$ & $\begin{array}{l}0.304 \\
0.116\end{array}$ & $\begin{array}{l}-.277- \\
0.153\end{array}$ & 1.000 & & & \\
\hline GOVOW & $\begin{array}{l}.446^{*} \\
0.017\end{array}$ & $\begin{array}{l}0.118 \\
0.55\end{array}$ & $\begin{array}{l}0.174 \\
0.376\end{array}$ & $\begin{array}{l}-.033- \\
0.868\end{array}$ & $\begin{array}{c}-.033- \\
0.868\end{array}$ & 1.000 & & \\
\hline DOMI & $\begin{array}{l}.455^{*} \\
0.015\end{array}$ & $\begin{array}{l}0.183 \\
0.353\end{array}$ & $\begin{array}{l}0.068 \\
0.732\end{array}$ & $\begin{array}{l}0.002 \\
0.992\end{array}$ & $\begin{array}{l}0.002 \\
0.992\end{array}$ & $\begin{array}{l}.468 * \\
0.012\end{array}$ & 1.000 & \\
\hline CDIV & $\begin{array}{l}.527^{* *} \\
0.004\end{array}$ & $\begin{array}{l}0.22 \\
0.26\end{array}$ & $\begin{array}{l}0.107 \\
0.587\end{array}$ & $\begin{array}{l}0.161 \\
0.414\end{array}$ & $\begin{array}{l}0.161 \\
0.414\end{array}$ & $\begin{array}{l}.401 * \\
0.035\end{array}$ & $\begin{array}{l}.534 * * \\
0.003\end{array}$ & 1.000 \\
\hline
\end{tabular}

Note. **. Correlation is significant at the 0.01 level (2-tailed).

*. Correlation is significant at the 0.05 level (2-tailed).

Table 3 pointed to several significant correlations between the independent variables. Positive and significant association appeared between size and leverage, size and industry type, size and government ownership, size and the number of dominant personalities serving on a company's board of directors and size and the amount of cash dividends. Positive and significant correlation also found between the percentage of shares owned by government and the number of dominant personalities serving on a company's board of directors, and paid cash dividends and the number of dominant personalities serving on a company's board of directors. The results of the correlation is predictable. Large sized companies are expected to look for different sources of fund to finance their activities. Hence, they are expected to have high levels of leverage than small sized companies. Industry is also associated with corporate size, since industrial companies are expected to be larger in size than services companies. Similarly, the positive and significant association between the surveyed companies' size and the percentage of shares owned by the government is logical since large companies are more likely to look for government investment than small companies. Furthermore, large companies embark on too many transactions and they need personal contacts to facilitate completing them. Hence, they need more dominant personalities to serve on their board. Finally, the positive and significant association between the surveyed companies size and dividends payout is explained on the ground that these large companies reached an advanced level of development and there is little scope for their growth. However, small sized companies may retain significant part of their profit for future expansion and growth. In all cases, none of the resulted correlations between the independent variables exceeded the 0.70 benchmark for possible collinearity problem. Thus, collinearity does not seem to be a serious problem and the multi-regression analysis was undertaken. The result of the multi-regression is presented in Table 4.

\subsection{Regression}

The result of the backward multi-regression analysis reported in Table 4 demonstrated that all independent variables are positively associated with the quality of corporate reporting of the non-financial companies listed on ADX except for the number of dominant personalities serving on the company's board of directors. Three of the four estimated regression models confirmed that the quality of corporate reporting is positively and significantly associated with corporate size, leverage, age and industry. A negative and significant association appeared between the quality of corporate disclosure and the number of dominant personalities serving the company's board of directors. In other words, long established, large sized, highly leveraged and industry type of the non-financial companies are more likely to have high quality reporting than other companies. On the other hand, companies with several dominant personalities serving on their board of directors are more likely to produce low quality reporting. Management would hide behind dominant personalities and publish less information. 
Table 4. Regression analysis

\begin{tabular}{|c|c|c|c|c|}
\hline Model 1 & $\mathrm{R}^{2}=0.678$ & Adjusted $\mathrm{R}^{2}=0.542$ & $\mathrm{~F}=4.991$ & Sig. $F=.002$ \\
\hline & Variables & Beta & $\mathrm{t}$ & Sig. \\
\hline & Constant & & 1.788 & .090 \\
\hline & $S I Z E$ & .431 & 1.999 & .060 \\
\hline & PROFIT & .052 & .321 & .752 \\
\hline & $L E V$ & .382 & 2.434 & .025 \\
\hline & Age & .254 & 1.532 & .142 \\
\hline & $I N D S$ & .306 & 1.361 & .189 \\
\hline & GOVOW & .093 & .592 & .561 \\
\hline & DOMI & -.405 & -2.410 & .026 \\
\hline & $C D I V$ & .060 & .253 & .803 \\
\hline \multirow[t]{10}{*}{ Model 2} & $\mathrm{R}^{2}=0.676$ & Adjusted $\mathrm{R}^{2}=0.563$ & $\mathrm{~F}=5.974$ & Sig. $F=.001$ \\
\hline & Variables & Beta & $\mathrm{t}$ & Sig. \\
\hline & Constant & & 1.893 & .073 \\
\hline & SIZE & .446 & 2.192 & .040 \\
\hline & PROFIT & .071 & .515 & .612 \\
\hline & $L E V$ & .378 & 2.479 & .022 \\
\hline & Age & .276 & 1.979 & .062 \\
\hline & $I N D S$ & .341 & 1.973 & .062 \\
\hline & GOVOW & .097 & .637 & .531 \\
\hline & DOMI & $-.396-$ & $-2.465-$ & .023 \\
\hline \multirow[t]{9}{*}{ Model 3} & $\mathrm{R}^{2}=0.672$ & Adjusted $\mathrm{R}^{2}=0.579$ & $\mathrm{~F}=8.722$ & Sig. $F=.000$ \\
\hline & Variables & Beta & $\mathrm{t}$ & Sig. \\
\hline & Constant & & 1.959 & .064 \\
\hline & SIZE & .446 & 2.235 & .036 \\
\hline & $L E V$ & .375 & 2.504 & .021 \\
\hline & Age & .272 & 1.992 & .060 \\
\hline & $I N D S$ & .314 & 1.941 & .066 \\
\hline & GOVOW & .103 & .693 & .496 \\
\hline & DOMI & $-.377-$ & $-2.455-$ & .023 \\
\hline \multirow[t]{8}{*}{ Model 4} & $\mathrm{R}^{2}=.665$ & Adjusted $\mathrm{R}^{2}=0.588$ & $\mathrm{~F}=7.177$ & Sig. $F=.000$ \\
\hline & Variables & Beta & $\mathrm{t}$ & Sig. \\
\hline & Constant & & 1.865 & .076 \\
\hline & SIZE & .482 & 2.532 & .019 \\
\hline & $L E V$ & .377 & 2.545 & .018 \\
\hline & Age & .279 & 2.068 & .051 \\
\hline & $I N D S$ & .307 & 1.924 & .067 \\
\hline & DOMI & $-.343-$ & $-2.386-$ & .026 \\
\hline
\end{tabular}

\section{Conclusion}

At the end of 2012, the number of the non-financial companies listed on ADX was 31.28 of these companies are considered Emirati companies and published their annual reports for the years 2010-2012 on ADX website. These companies are distributed among 14 industries: 6 services, manufacturing, 4 food staples, 2 energy, 1 real estate and 1 communications. This indicates that ADX still has a limited number of companies. The size of the non-financial companies, measured by the average total assets at the end of years 2010-2012 varies between AED 0.4 billion and AED 118 billion. The average size of all companies over the period of study was around AED 11 billion. During the period between 2010-2012, 5 of the surveyed companies reported loss at least in one year, 4 reported losses at least in two years, only one company reported losses for the three years covered in the study. Net income to assets during the mentioned period ranged from $-9 \%$ to $12 \%$. As far as the level of leverage of the companies at the end of the years for the period between 2010-2012, measured by total liabilities to total assets, it ranges between 0.06 up to $88 \%$. The reported mean of leverage ratio indicates that the level of leverage is relatively low. The surveyed companies still rely on equity to finance their assets. This is in line with the Islamic culture of the UAE that prohibits riba (paying or receiving interest on loans). The age of the non-financial companies-between the year of their incorporation and 2012-ranges between 6-40 years. The average age of the companies is around 25 years. As for the government ownership of the non-financial companies, government owns $18 \%$ of the shares of non-financial companies listed on ADX. It owns more than $50 \%$ of the shares of 6 companies. 21 of the surveyed non-financial companies listed on ADX paid dividends in each of the three years covered in the study, 2 paid dividends in only two years, 2 paid dividends in only one year and 3 companies did not pay dividends in any of the three years. 
The multi-regression analyses pointed to five variables as being the major determinant of the quality of corporate reporting of the sample companies: size measured by total assets, leverage, age, industry, and the presence of dominant personality serving on the company's board of directors. While the first four variables appeared to be positively and significantly associated with the quality of corporate reporting, the last variable was negatively and significantly related to the quality of reporting.

\section{Acknowledgements}

Views and opinions expressed in this article are those of the authors and do not relflect views and opinions of their employers.

\section{References}

Akhtaruddin, M. (2005). Corporate Mandatory Disclosure Practices in Bangladesh. The International Journal of Accounting, 40, 399-422. http://dx.doi.org/10.1016/j.intacc.2005.09.007

Al-Janadi1, Y., Abdul Rahman, R., \& Haj Omar, N. (2013). Corporate Governance Mechanisms and Voluntary Disclosure in Saudi Arabia. Research Journal of Finance and Accounting, 4(4), 25-35.

Al-Shammari, B. (2008). Voluntary Disclosure in Kuwait Corporate Annual Reports. Review of Business Research, 1, 10-30.

AL-Shubiri, F. N., Al-Abedallat, A. Z., \& Abu Orabi, M. M. (2013). Financial and Non-Financial Determinants of Corporate Social Responsibility. Asian Economic and Financial Review, 2(8), 1001-1012.

Aly, D., Simon, J., \& Hussainey, K. (2010). Determinants of corporate internet reporting: Evidence from Egypt. Managerial Auditing Journal, 25(2), 182-202. http://dx.doi.org/10.1108/02686901011008972

Barako, D. G. (2006). Factors influencing voluntary corporate disclosure by Kenyan companies. Corporate Governance: An International Review, 14(2), 107-125. http://dx.doi.org/10.1111/j.1467-8683.2006.00491.x

Bernstein, L. (1982). Financial Statement Analysis: Theory Application, and Interpretation (3rd ed.). Homewood, IL: Richard D. Irwin.

Bujaki, M., \& McConomy, B. J. (2002). Corporate Governance: Factors Influencing Voluntary Disclosure by Publicly Traded Canadian Firms. Canadian Accounting Perspectives, 1(2), 105-139. http://dx.doi.org/10.1506/9FN9-ECC9-7GL7-25NT

Buzby, S. L. (1975). Company Size, Listed Versus Unlisted Stocks, and the Extent of Financial Disclosure. Journal of Accounting Research, 13, 16-37. http://dx.doi.org/10.2307/2490647

Camfferman, K., \& Cooke, T. (2002). An Analysis of Disclosure in the Annual Reports of UK and Dutch Companies. Journal of International Accounting Research, 1, 3-30. http://dx.doi.org/10.2308/jiar.2002.1.1.3

Chau, K. G., \& Gray, S. J. (2002). Ownership Structure and Corporate Voluntary Disclosure in Hong Kong and $\begin{array}{llll}\text { Singapore. International Journal of } & \text { Accounting, 37(2), }\end{array}$ http://dx.doi.org/10.1016/S0020-7063(02)00153-X

Chow, C. W., \& Wong-Boren, A. (1987). Voluntary Financial Disclosure by Mexican Corporations. The Accounting Review, 533-541.

Clarkson, P., Guedes, J., \& Thompson, R. (1996). On the diversification, observability, and measurement of estimation risk. Journal of Financial and Quantitative Analysis, 31(1), 69-84. http://dx.doi.org/10.2307/2331387

Cooke, T. E. (1989a). Disclosure in the Corporate Annual Reports of Swedish Companies. Accounting and Business Research, 19(74), 113-124. http://dx.doi.org/10.1080/00014788.1989.9728841

Cooke, T. E. (1989b). Voluntary Corporate Disclosure by Swedish Companies. Journal of International Financial Management and Accounting, 1, 171-195. http://dx.doi.org/10.1111/j.1467-646X.1989.tb00009.x

Cooke, T. (1992). The Impact of Size, Stock Market Listing and Industry Type on Disclosure in the Annual Reports of Japanese Listed Corporations. Accounting and Business Research, 22(7), 229-237. http://dx.doi.org/10.1080/00014788.1992.9729440

Cooke, T. E. (1993). Disclosure in Japanese Corporate Annual Reports. Journal of Business Finance and Accounting, 20(4), 521-535. http://dx.doi.org/10.1111/j.1468-5957.1993.tb00272.x

Craswell, A. T., \& Taylor, S. L. (1992). Discretionary Disclosure of Reserves by Oil and Gas Companies: An 
Economic Analysis. Journal of Business Finance and Accounting, 19(2), 295-308. http://dx.doi.org/10.1111/j.1468-5957.1992.tb00626.x

Depoers, F. (2000). A Cost Benefit Study of Voluntary Disclosure: Some Empirical Evidence from French Listed Companies. European Accounting Review, 9(2), 245-263. http://dx.doi.org/10.1080/09638180050129891

Fama, E. F., \& Jensen, M. C. (1983). Separation of Ownership and Control. Journal of Law and Economics, 26(2), 301-325. http://dx.doi.org/10.1086/467037

Ferguson, M. J., Lam, K. C. K., \& Lee, G. M. (2002). Voluntary Disclosure by State Owned Enterprises Listed on the Stock Exchange of Hong Kong. Journal of International Financial Management and Accounting, 13(2), 125-152. http://dx.doi.org/10.1111/1467-646X.00081

Haji, A., \& Ghazali, N. A. M. (2013). The quality and determinants of voluntary disclosures in annual reports of Shari'ah compliant companies in Malaysia. Humanomics, 29(1), 24-42. http://dx.doi.org/10.1108/08288661311299303

Galani, D., Alexandridis, A., \& Stavropoulos, A. (2011). The Association between the Firm Characteristics and Corporate Mandatory Disclosure the Case of Greece. World Academy of Science, Engineering and Technology, 77, 101-107.

Glaum, M., \& Street, D. (2003). Compliance with the Disclosure Requirement of German's New Market, IAS Versus US GAAP. Journal of International Financial Management and Accounting, 14(1), 64-100. http://dx.doi.org/10.1111/1467-646X.00090

Haniffa, R. M., \& Cooke, T. E. (2002). Culture, Corporate Governance and Disclosure in Malaysian Corporations. Abacus, 38(3), 317-350. http://dx.doi.org/10.1111/1467-6281.00112

Healy, P. M., \& Palepu, K. G. (2001). Information asymmetry, corporate disclosure, and the capital markets: A review of the empirical disclosure literature. Journal of Accounting and Economics, 31(1-3), 405-440. http://dx.doi.org/10.1016/S0165-4101(01)00018-0

Hossain, M., \& Hammami, H. (2009). Voluntary Disclosure in the Annual Reports of an Emerging Country: The case of Qatar. Advances in Accounting, incorporating Advances in International Accounting, 25, 255-265. http://dx.doi.org/10.1016/j.adiac.2009.08.002

Inchausti, B. G. (1997). The Influence of Company Characteristics and Accounting Regulation on Information Disclosed by Spanish Firms. The European Accounting Review, 6(1), 45-68. http://dx.doi.org/10.1080/096381897336863

Juhmani, O. I. (2013). Ownership Structure and Corporate Voluntary Disclosure: Evidence from Bahrain. Accounting and Financial Reporting, 3(2), 133-143. http://dx.doi.org/10.5296/ijafr.v3i2.4088

McKinnon, J. L., \& Dalimunthe, L. (1993). Voluntary Disclosure of Segment Information by Australian $\begin{array}{llll}\text { Diversified } \quad \text { Companies. } & \text { Accounting and }\end{array}$ http://dx.doi.org/10.1111/j.1467-629X.1993.tb00192.x

Makhija, A. K., \& Patton, J. M. (2004). The Impact of Firm Ownership Structure on Voluntary Disclosure: Empirical Evidence from Czech Annual Reports. Journal of Business, 77(3), 457-491. http://dx.doi.org/10.1086/386526

Malone, D., Fries, C., \& Jones, T. (1993). An Empirical Investigation of the Extent of Corporate Financial Disclosure in the Oil and Gas Industry. Journal of Accounting, Auditing and Finance, 8(3), 249-273.

McNally, G. M., Eng, L. H., \& Hasseldine, C. R. (1982). Corporate Financial Reporting in New Zealand: An Analysis of User Preferences, Corporate Characteristics and Disclosure Practices for Discretionary $\begin{array}{lllll}\text { Information. Accounting and } \quad \text { Business } & \text { Research, } & \text { 13, }\end{array}$ http://dx.doi.org/10.1080/00014788.1982.9729725

Meek, G. K., Roberts, C. B., \& Gray, S. J. (1995). Factors Influencing Voluntary Annual Report Disclosures by U.S., U.K., \& Continental European Multinational Corporations. Journal of International Business Studies, 26(3), 555-572. http://dx.doi.org/10.1057/palgrave.jibs.8490186

Naser, K. (1998). Comprehensiveness of Disclosure of Nonfinancial Companies Listed on the Amman Financial Market. International Journal of Commerce \& Management, 2(8), 88-119. http://dx.doi.org/10.1108/eb047365

Naser, K., Al-Khatib, K., \& Karbhari, R. (2002). Empirical Evidence on the Depth of Corporate Information 
Disclosure in Developing Countries: The Case of Jordan. International Journal of Commerce and Management, 12(3\&4), 122-155. http://dx.doi.org/10.1108/eb047456

Othman, R., Thani, A., \& Ghani, E. (2009). Determinants of Islamic Social Reporting Among Top Shariah-Approved Companies in Bursa Malaysia. Research Journal of Internatıonal Studies, 12, 4-20.

Owusu-Ansah, S. (1998). The Impact of Corporate Attributes on the Extent of Mandatory Disclosure and Reporting by Listed Companies in Zimbabwe. The International Journal of Accounting, 33(5), 605-631. http://dx.doi.org/10.1016/S0020-7063(98)90015-2

Prencipe, A. (2004). Proprietary Costs and Determinants of Voluntary Segment Disclosure: Evidence from Italian Listed Companies. European Accounting Review, 13(2), 319-340. http://dx.doi.org/10.1080/0963818042000204742

Raffournier, B. (1995). The Determinants of Voluntary Financial Disclosure by Swiss Listed Companies. European Accounting Review, 4(2), 261-280. http://dx.doi.org/10.1080/09638189500000016

Robbins, W. A., \& Austin, K. R. (1986). Disclosure Quality in Governmental Financial Reports: An Assessment of the Appropriateness of a Compound Measure. Journal of Accounting Research, 24(2), 412-421. http://dx.doi.org/10.2307/2491145

Singhvi, S. S. (1968). Disclosure to Whom? Annual Financial Reports to Stockholders and to the Securities and Exchange Commission. The Journal of Business, 41, 347-351. http://dx.doi.org/10.1086/295112

Singhvi, S. S., \& Desai, H. B. (1971). An empirical analysis of the quality of corporate financial disclosure. The Accounting Review, 46(1), 129-138.

Suleiman, M., Abdullah, N., \& Fatima, A. H. (2104). Determinants of Environmental Reporting Quality in Malaysia. International Journal of Economics, Management and Accounting, 22(1), 63-90.

Tower, G., Hancock, P., \& Taplin, R. H. (1999). A regional Study of Listed Companies' Compliance with International Accounting Standards. Accounting Forum, 23(3), 293-305. http://dx.doi.org/10.1111/1467-6303.00016

Uyar, A. (2012). Determinants of corporate reporting on the internet: An analysis of companies listed on the Istanbul Stock Exchange (ISE). Managerial Auditing Journal, 27(1), 87-104. http://dx.doi.org/10.1108/02686901211186117

Wallace, R. S. O., \& Naser, K. (1995). Firm-Specific Determinants of the Comprehensiveness of Mandatory Disclosure in the Corporate Annual Reports of Firms Listed on the Stock Exchange of Hong Kong. Journal of Accounting and Public Policy, 14, 311-368. http://dx.doi.org/10.1016/0278-4254(95)00042-9

Wallace, R. S. O., Naser, K., \& Mora, A. (1994). The Relationship between the Comprehensiveness of Corporate Annual Reports and Firm Characteristics in Spain. Accounting and Business Research, 25(97), 41-53. http://dx.doi.org/10.1080/00014788.1994.9729927

\section{Notes}

Note 1 . The choice of non-financial companies was based on the grounds that these companies are governed by Company Law and listing requirements of ADX. Whereas, financial companies are governed by the central bank regulations and the listing requirements of ADX. In addition, there is a significant difference in the capital structure of financial and nonfinancial companies and this will affect corporate disclosure. Thus, the current study will be cover nonfinancial companies.

Note 2. GCC countries include Bahrain, Kuwait, Oman, Qatar, Saudi Arabia and UAE.

Note 3. Any views expressed in this paper are those of the authors only and not those of their employers.

Note 4. Financial companies include banking, insurance and investment.

\section{Copyrights}

Copyright for this article is retained by the author(s), with first publication rights granted to the journal.

This is an open-access article distributed under the terms and conditions of the Creative Commons Attribution license (http://creativecommons.org/licenses/by/3.0/). 